\title{
Oxidation of Gabapentin by Potassium Ferrate (VI) in Alkaline Media-Kinetics and Mechanism Study
}

\author{
Hongru Liu, Dan Wang, Jinhuan Shan* \\ College of Chemistry and Environmental Science, Hebei University, Key Laboratory of Analytical \\ Science and Technology of Hebei Province, Baoding, 071002 Hebei, China
}

\begin{abstract}
In the present research, the reaction kinetics of Potassium Ferrate (VI) with gabapentin were studied by using spectrophotometer. The reaction was determined under alkaline condition at the different temperatures of $288.2 \mathrm{~K}-308.2 \mathrm{~K}$. All data was obtained from the pseudo-first order reaction. It was found that the reaction is a first-order for reactant. The observed rates constants $\left(k_{o b s}\right)$ increased with increasing [reductant], however, increasing $\left[\mathrm{OH}^{-}\right]$, the $k_{\text {obs }}$ decreased. The reaction is negative fraction order with respect to [OH']. The reasonable mechanism has been suggested to explain the experimental data. The rate constants of the rate-determining step and the thermodynamic activation parameters at $298.2 \mathrm{~K}$ were calculated.
\end{abstract}

Keywords: Potassium Ferrate (VI), Gabapentin, Oxidation, Mechanism, Kinetics

\section{INTRODUCTION}

In recent years, Potassium Ferrate (VI) has been more widely used in water pollution. It has been used as a multipurpose wastewater chemical for oxidation, coagulation, deodorization and disinfection [1-3]. For instance, it could oxidize sulfur-containing compounds [4] which effectively reducing odor problems. It was used for sludge [5] treatment to effectively improve the quality of sludge. The cyanide [6, 7] of highly toxic substance was out by Ferrate (VI) that remained availability, effectiveness, and economics and reduced pollution. It could remove heavy metals [8] and arsenic (III) [9] so reduce them to human chronic poisoning. It could remove algaes [10] and microcystins [11] from aqueous solutions that effectively controlled the global problem of eutrophication of freshwater and coastal marine ecosystems and reduced the threat to human health of cyanotoxin. It can be seen that Ferrate (VI) plays an important role in the treatment of water pollution. Furthermore, emerging organic contamination has been more and more attention. They have potential environmental threat to human and aquatic organisms. Ferrate (VI) has been evaluated as water treatment for them [12]. For example, it oxidized endocrine disrupting such as estrogenic compounds [13], pharmaceuticals such as nonylphenol [14] and antibiotics [15,16]. In a word, Potassium Ferrate (VI) has displayed many advantages such as higher selectivity, reactivity and non-toxic ferric ion of by-product as environmentally friendly water. In addition, Ferrate (VI) has been utilized rationally and effectively in other ways such as super-iron batteries [17].

Ferrate (VI) is tetrahedral in structure; the feature of all Fe-O bonds is covalently. Fe (VI) sorts are strong oxidizing agents with an oxidation potential of $\mathrm{E}_{0}=+2.2 \mathrm{~V}$ in acidic media and $\mathrm{E}_{0}=+0.72 \mathrm{~V}$ in alkaline media [18]. Fe (VI) ion has maximum absorption wavelength at $510 \mathrm{~nm}$ in aqueous solution $\left(\varepsilon 510 \mathrm{~nm}=1150 \mathrm{~L} \cdot \mathrm{mol}^{-1} \cdot \mathrm{cm}^{-1}\right)$ [19], which is very commonly used to ensure its concentration. The reaction mechanism of Potassium Ferrate is divided into two kinds: one is one-electron pathway, the other is two-electron pathway [12]. Thus, according to the different reaction system, the reaction mechanism needs to be further studied. 
Gabapentin is prescribed in combination with other medicines to prevent seizure of people suffering from seizure disorders. It is sometimes used to treat nerve pain.

In this paper, we report the potassium ferrate oxidation of gabapentin, further more, the kinetics and reaction mechanisms were studied.

\section{EXPERIMENTAL}

\subsection{Materials}

Potassium Ferrate (VI) was prepared based on the method of Thompson etal [20]. All the matters were used of AR grade. Solutions were prepared with water that had been doubly distilled. Buffer solutions were prepared with mixing $\mathrm{Na}_{2} \mathrm{HPO}_{4}$ and $\mathrm{NaOH}$, and Ionic strength was kept with $\mathrm{KNO}_{3}$. The Potassium Ferrate (VI) solutions were prepared of buffer solutions and the phosphate was a complexing agent for Fe (III) that prevented precipitation of iron hydroxides that obstructs with the optical detecting of the reaction and promotes the self-decomposition of $\mathrm{Fe}(\mathrm{VI})$. The concentration of potassium ferrate was calculated by using its absorption at $510 \mathrm{~nm}\left(\varepsilon=1150 \mathrm{~L} \cdot \mathrm{mol}^{-1} \cdot \mathrm{cm}^{-1}\right)$ [19]. Reductant was also prepared with buffer solutions.

\subsection{Methods}

A US-vis. Spectrophotometer (TU-1950, Beijing Puxi Inc, China) with fixed a thermostat (RAB, Germany, $\pm 0.1 \mathrm{~K})$ was used to perform the kinetic measurements under pseudo-first order conditions with gabapentin in excess. The concentration of $\mathrm{Fe}(\mathrm{VI})$ in the experiments were $1.0 \times 10^{-4} \mathrm{~mol} \cdot \mathrm{L}^{-1}$, while the gabapentin concentration ranged from $1.0 \times 10^{-3}$ to $5.0 \times 10^{-3} \mathrm{~mol} \cdot \mathrm{L}^{-1}$. Experiment processes were monitored by measuring the absorbance of $\mathrm{Fe}(\mathrm{VI})$ at $510 \mathrm{~nm}$ wavelength as a function of time where other species were not any interference under the given conditions.

\subsection{Product Analysis}

There is no ferric oxy hydroxides precipitate in the solution where the reaction was carried out under the phosphate-buffered aerobic. The precence of the Fe (III) was detected by adding the potassium thiocyanate to the spent solutions to produce the red ferric thiocyanate complex. Under the anaerobic conditions, the Fe (III) was found the only iron species again [21].

\subsection{Reaction Intermediate}

As a check for the production of $\mathrm{Fe}$ (II) as an intermediate during the reduction of $\mathrm{Fe}$ (VI) was demonstrated by the addition of 1,10-phenanthroline to the reductant solution [22], then mixing with the Ferrate (VI) solution to produce the orange red $\left[\mathrm{Fe}(\mathrm{phen})_{3}\right]^{2+}$. It is obviously that the process of $\mathrm{Fe}$ (VI) reduced to Fe (III) with Fe (II) stage.

\section{RESUltS AND DisCUSSION}

Reactions were measured by observing the absorbance of Fe (VI) at $510 \mathrm{~nm}$ wavelength as a function of time. It was shown that the reaction is first order on the basis of the characteristic of pseudo-first order and the plots of $\ln \left(\mathrm{A}_{\mathrm{t}}-\mathrm{A}_{\infty}\right)$ versus $\mathrm{t}$ were straight line under the conditions of $[\text { reductant }]_{0}>>[\mathrm{Fe}(\mathrm{VI})] 0$. Where At is the absorbance at time $\mathrm{t}$ and $\mathrm{A}_{\infty}$ is at infinite time. The reactions were used at least 3 half-lives and the pseudo-first-order rate constants kobs were calculated. The kobs values were the average values of three parallel experiments and relative deviation is among $\pm 5 \%$.

\subsection{The effect of [Reductant] on the Reaction Rates}

In the first series of experiments, where $[\mathrm{Fe}(\mathrm{VI})]$ and $\left[\mathrm{OH}^{-}\right]$were constant concentrations and ionic strength was $1.00 \mathrm{~mol} \cdot \mathrm{L}^{-1}$. The $k_{o b s}$ of the reaction were measured as a function of [reductant] at 
different temperatures $(288.2 \mathrm{~K}-308.2 \mathrm{~K})$. It was found to be that the values of $k_{o b s}$ increase linearly with increasing of the reductant concentrations. The plots of $k_{o b s}$ versus [reductant] were linear and passed through the origin (Fig.1). The linear dependence observes a first-order term with reductant.

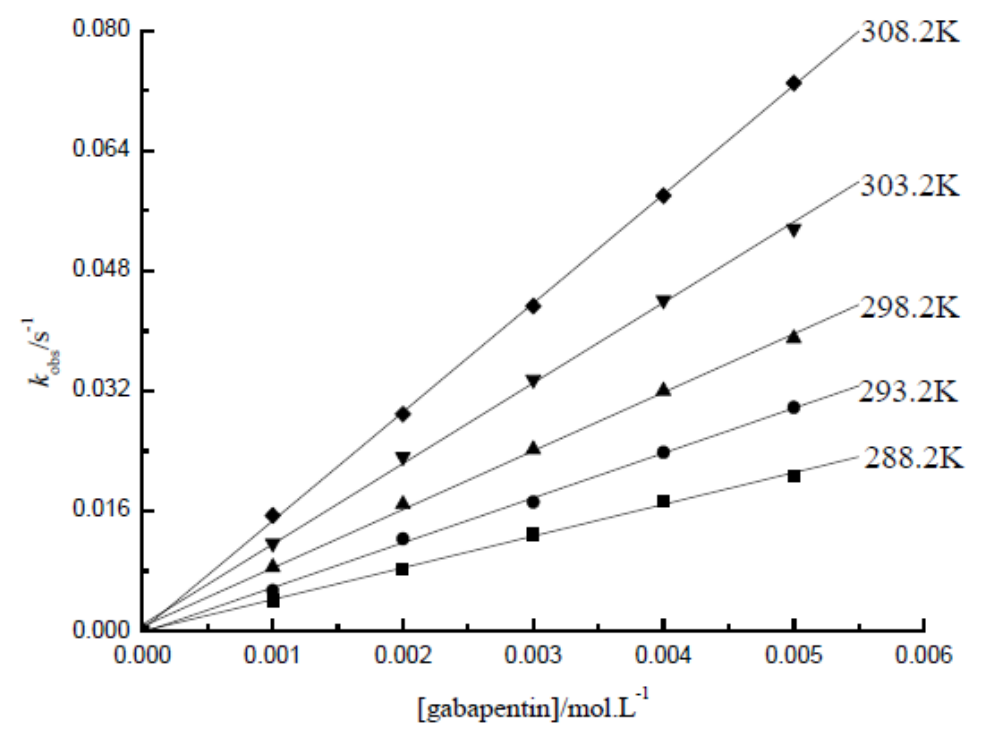

Fig1. Plots of kobs versus [gabapentin] at diffirent temperatures. $[\mathrm{Fe}(\mathrm{VI})]=1.00 \times 10^{-4} \mathrm{~mol} \cdot \mathrm{L}^{-1}$, $\left[\mathrm{OH}^{-}\right]=2.51 \times 10^{-5} \mathrm{~mol} \cdot \mathrm{L}^{-1}, I=1.00 \mathrm{~mol} \cdot \mathrm{L}^{-1}, r \geq 0.999$

\subsection{The Effect of $\left[\mathrm{OH}^{-}\right]$on the Reaction Rates}

In the next series of experiments, where [Fe (VI)], [reductant] and ionic strength were constant. The $k_{o b s}$ decreased with increasing of $\left[\mathrm{OH}^{-}\right]$at different temperature ranged from $288.2 \mathrm{~K}-308.2 \mathrm{~K}$. The plot of $1 / k_{o b s}$ versus $\left[\mathrm{OH}^{-}\right]$was linear and the reaction order as a function of $\left[\mathrm{OH}^{-}\right]$was found to be negative fractional (Fig 2).

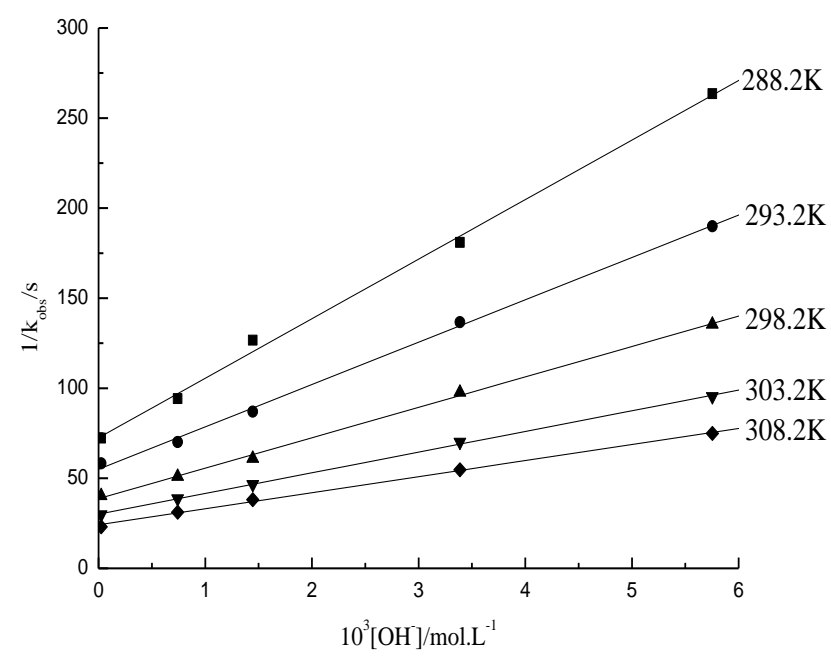

Fig2. Plots of $1 / \mathrm{kobs}$ versus $\left[\mathrm{OH}^{\top}\right]$ at diffirent temperatures. $[\mathrm{Fe}(\mathrm{VI})]=1.00 \times 10^{-4} \mathrm{~mol} \cdot \mathrm{L}^{-1}$, [gabapentin] $=3.00 \times 10^{-3} \mathrm{~mol} \cdot \mathrm{L}^{-1}, I=1.00 \mathrm{~mol} \cdot \mathrm{L}^{-1} . r \geq 0.999$.

\subsection{The Effect of Ionic Strength on the Reaction Rates}

In the last series of experiments, where [Fe (VI)], [reductant] and $\left[\mathrm{OH}^{-}\right]$were fixed. The $k_{\text {obs }}$ were monitored at different ionic strength in $298.2 \mathrm{~K}$. The results showed that increasing of the ionic strength, the $k_{o b s}$ were no basic change (Table 1), thus, the reaction had no salt effect. 
Table1. The diffirent $k o b s$ in the $298.2 \mathrm{~K} . \quad[\mathrm{Fe}(\mathrm{VI})]=1.00 \times 10^{-4} \mathrm{~mol} \cdot \mathrm{L}^{-1}$, [gabapentin] $=3.00 \times 10^{-3} \mathrm{~mol} \cdot \mathrm{L}^{-1}$, $[\mathrm{OH}-]=2.51 \times 10-5 \mathrm{~mol} \cdot \mathrm{L}^{-1}$

\begin{tabular}{|l|l|l|l|l|l|}
\hline$\mu / \mathrm{mol}_{\mathrm{L}} \mathrm{L}^{-1}$ & 0.6 & 0.7 & 0.8 & 0.9 & 1.0 \\
\hline $10^{3} k_{\text {obs }} / \mathrm{s}^{-1}$ & 24.10 & 24.61 & 24.63 & 24.22 & 24.24 \\
\hline
\end{tabular}

\subsection{Reaction Mechanism}

It was known that Ferrate (VI) is a dicarboxylic acid [22], where:

$$
\begin{aligned}
& \mathrm{H}_{2} \mathrm{FeO}_{4} \rightleftharpoons \mathrm{HFeO}_{4}^{-}+\mathrm{H}^{+}, \mathrm{pK}_{\mathrm{a}_{1}}=3.5 \\
& \mathrm{HFeO}_{4}^{-} \rightleftharpoons \mathrm{FeO}_{4}^{2-}+\mathrm{H}^{+}, \mathrm{p} K_{\mathrm{a}_{2}}=7.8
\end{aligned}
$$

Under the conditions of experimental in this study, equation (2) is more probable basing on the $\mathrm{p} K_{a 2}$ value. If $\mathrm{HFeO}_{4}{ }^{-}$is to be the reactive species, the rate should decrease with increasing $\mathrm{pH}$. $\mathrm{HFeO}_{4}{ }^{-}$has been shown to be the most likely reactive species in the present study.

Thus, $\mathrm{FeO}_{4}{ }^{2-}$ will be partial hydrolysis:

$$
\mathrm{FeO}_{4}^{2-}+\mathrm{H}_{2} \mathrm{O} \rightleftharpoons \mathrm{HFeO}_{4}^{-}+\mathrm{OH}^{-}
$$

Hence:

$$
K_{\mathrm{h}}=\frac{\left[\mathrm{HFeO}_{4}^{-}\right]\left[\mathrm{OH}^{-}\right]}{\left[\mathrm{FeO}_{4}^{2-}\right]}=\frac{K_{\mathrm{w}}}{K_{\mathrm{a}_{2}}}=6.31 \times 10^{-7}
$$

Therefore:

$$
\frac{\left[\mathrm{HFeO}_{4}^{-}\right]}{\left[\mathrm{FeO}_{4}^{2-}\right]}=\frac{K_{\mathrm{h}}}{\left[\mathrm{OH}^{-}\right]}
$$

It is known clearly that the concentration of $\mathrm{HFeO}_{4}{ }^{-}$decreased with increasing of $\left[\mathrm{OH}^{-}\right]$and was very small, but it is very easy to form complex with reductant in the presence of the hydrogen atom and the complex has higher activity. Under the attack of hydroxyl ion, the complex is divided into Fe (IV) and products, then $\mathrm{Fe}(\mathrm{IV})$ with reductant further reacts to generate $\mathrm{Fe}(\mathrm{II})$ and products. Thus, the reaction is mostly through $\mathrm{HFeO}_{4}{ }^{-}$to achieve.

According to a series of discussions, the mechanism may be written as shown:

$$
\begin{aligned}
\mathrm{FeO}_{4}^{2-}+\mathrm{H}_{2} \mathrm{O} \underset{ }{\stackrel{k_{\mathrm{h}}}{\rightleftharpoons}} \mathrm{HFeO}_{4}^{-}+\mathrm{OH}^{-} \\
\mathrm{HFeO}_{4}^{-}+\mathrm{R} \underset{k_{-2}}{\stackrel{k_{2}}{\rightleftharpoons}} \mathrm{X} \\
\mathrm{X}+\mathrm{OH}^{-} \stackrel{k_{3}}{\longrightarrow} \mathrm{Fe}(\mathrm{IV})+\text { Products } \\
\mathrm{Fe}(\mathrm{IV})+\mathrm{R} \stackrel{k_{4}}{\longrightarrow} \mathrm{Fe}(\mathrm{II})+\text { Products } \\
\mathrm{Fe}(\mathrm{IV})+\mathrm{Fe}(\mathrm{II}) \stackrel{k_{5}}{\longrightarrow} 2 \mathrm{Fe}(\mathrm{III})
\end{aligned}
$$

The equation (4) is the rate-controlling step, where $\mathrm{R}$ stands for reductant. The rate of Fe (VI) disappearance can be written as:

$$
-\frac{\mathrm{d}\left[\mathrm{FeO}_{4}^{2-}\right]}{\mathrm{dt}}=k_{2}\left[\mathrm{HFeO}_{4}^{-}\right][\mathrm{R}]-k_{-2}[\mathrm{X}]
$$


$[\mathrm{X}]$ can be got on the basis of static state method and equation of (4) and (5):

$$
[\mathrm{X}]=\frac{k_{2}\left[\mathrm{HFeO}_{4}^{-}\right][\mathrm{R}]}{k_{-2}+k_{3}\left[\mathrm{OH}^{-}\right]}
$$

According to equation (8) and (9), we get equation (10)

$$
-\frac{\mathrm{d}\left[\mathrm{FeO}_{4}^{2-}\right]}{\mathrm{dt}}=\frac{k_{2} k_{3}\left[\mathrm{HFeO}_{4}^{-}\right][\mathrm{R}]\left[\mathrm{OH}^{-}\right]}{k_{-2}+k_{3}\left[\mathrm{OH}^{-}\right]}
$$

Taking equation (3) we get equation (11):

$$
\left[\mathrm{HFeO}_{4}^{-}\right]=\frac{K_{\mathrm{h}}\left[\mathrm{FeO}_{4}^{2-}\right]}{\left[\mathrm{OH}^{-}\right]}
$$

Taking equation (11) into equation (10) we get equation (12)

$$
\begin{aligned}
-\frac{\mathrm{d}\left[\mathrm{FeO}_{4}^{2-}\right]}{\mathrm{dt}} & =\frac{k_{2} k_{3} K_{\mathrm{h}}\left[\mathrm{FeO}_{4}^{2-}\right][\mathrm{R}]}{k_{-2}+k_{3}\left[\mathrm{OH}^{-}\right]} \\
& =\frac{k_{2} k_{3} K_{\mathrm{h}}[\mathrm{R}]}{k_{-2}+k_{3}\left[\mathrm{OH}^{-}\right]}\left[\mathrm{FeO}_{4}^{2-}\right]
\end{aligned}
$$

Hence:

$$
k_{\mathrm{obs}}=\frac{k_{2} k_{3} K_{\mathrm{h}}[\mathrm{R}]}{k_{-2}+k_{3}\left[\mathrm{OH}^{-}\right]}=\frac{k_{2} k^{\prime} K_{\mathrm{h}}[\mathrm{R}]}{1+k^{\prime}\left[\mathrm{OH}^{-}\right]}
$$

Where $k^{\prime}=\frac{k_{3}}{k_{-2}}$

Taking reciprocal of equation (13) we get equation (14)

$$
\frac{1}{k_{\mathrm{obs}}}=\frac{1+k^{\prime}\left[\mathrm{OH}^{-}\right]}{k_{2} k^{\prime} K_{\mathrm{h}}[\mathrm{R}]}=\frac{1}{k_{2} k^{\prime} K_{\mathrm{h}}[\mathrm{R}]}+\frac{\left[\mathrm{OH}^{-}\right]}{k_{2} K_{\mathrm{h}}[\mathrm{R}]}
$$

From what has been discussed above, we may finally draw the conclusions that the reaction should be first-order for reactant from the equation (12). The $k_{o b s}$ decreased with increasing $\left[\mathrm{OH}^{-}\right]$and $1 / k_{o b s}$ versus $\left[\mathrm{OH}^{-}\right]$was linear by the equation (14), which was consistent with the experimental phenomena. Basing on the equation (14) and the slopes of figure 2, the rate-controlling step constants $\left(k_{2}\right)$ were evaluated and the relational activation parameters date were obtained (Table 2) [23].

Table2. Rate constants of $(k 2)$ and thermodynamic activation parameters of the rate-controlling step

\begin{tabular}{|l|c|c|c|c|c|}
\hline $\mathrm{T}(\mathrm{K})$ & 288.2 & 293.2 & 298.2 & 303.2 .2 & 308.2 \\
\hline$k_{2} \cdot 10^{-4}\left(\mathrm{~mol}^{-1} \cdot \mathrm{L} \cdot \mathrm{s}^{-1}\right)$. & 1.60 & 2.25 & 3.13 & 4.60 & 5.97 \\
\hline $\begin{array}{l}\text { Thermodynamic activation } \\
\text { parameters }(298.2 \mathrm{~K})\end{array}$ & $\begin{array}{l}\mathrm{Ea} /\left(\mathrm{kJ} \cdot \mathrm{mol}^{-1}\right)=49.34, \Delta \mathrm{H}^{\neq} /\left(\mathrm{kJ}^{-1} \cdot \mathrm{mol}^{-1}\right)=46.86, \\
\Delta \mathrm{S}^{\neq} /\left(\mathrm{J} \cdot \mathrm{K}^{-1} \cdot \mathrm{mol}^{-1}\right)=-1.64\end{array}$ \\
\hline
\end{tabular}

The plots of $\ln k_{2}$ versus $1 / \mathrm{T}$ have the following intercept (a), slope (b) and relative coefficient (r): $\mathrm{a}=30.27, \mathrm{~b}=-5934.13, \mathrm{r}=0.998$.

\section{CONCluSion}

Based on the above discussion and related results, we can get the reaction mechanism of Potassium Ferrate (VI) with gabapentin in this study. Each oxidation is assumed to occur through a two-electron 
pathway. Thus, The Fe (VI) reacts with a molecule of reductant to form complex X. Then, the X dissociates into Fe (IV) and products under the attack of hydroxyl. Once more, the Fe (IV) with another molecule of reductant to form Fe (II) and products. Finally, The Fe (IV) reacts with Fe (II) to form $\mathrm{Fe}(\mathrm{III})$. In addition, the reaction has no salt effect. We also get the conclusion that the activation energy of reaction is small, while the entropy of activation has more negative values. The function of $\left[\mathrm{OH}^{-}\right]$and the activation parameters are consistent with experimental phenomena and provide the basis for kinetics studies.

\section{REFERENCES}

[1] Sharma V.K., Radek Zboril, Varma R.S. Ferrates: Greener Oxidants with Multimodal Action in Water Treatment Technologies. Acc. Chem. Res., 48 (2) (2015) 182-191.

[2] Umid Man Joshi, Rajasekhar Balasubramanian, Sharma V.K. Potential of Ferrate (VI) in Enhancing Urban Runoff Water Quality. ACS Symposium Series, 985 (30) (2008) 466-476.

[3] Jiang Q.H., Jin Z.S., Wang P. Preparation of Potassium Ferrate and Its Applications in Water treatment. Industrial Water Treatment,02 (2001) 4-6+37.

[4] Sharma V.K., Ma J., He C., Hyunook Kim, Radek Zborril Ferrate (VI): A Green Molecule in Odorous Gas Treatment. ACS Symposium Series, 1184 (12) (2014) 193-207.

[5] Jiang Q.J., Sharma V.K. The Use of Ferrate (VI) Technology in Sludge Treatment. ACS Symposium Series, 985 (18) (2008) 306-325.

[6] Sharma V.K., Wayne Rivera, Smith J.O., Brandon O'Brien Ferrate (VI) Oxidation of Aqueous Cyanide. Environ. Sci. Technol., 32 (17) (1998) 2608-2613.

[7] Yngard R.A., Sharma V.K., Jan Filip, Radek Zboril Ferrate (VI) Oxidation of weak-acid Dissociable Cyanids. Environ. Sci. Technol., 42 (8) (2008) 3005-3010.

[8] Robert Prucek, Jiř́i Tuček, Jan Kolařík, Ivana Hušková, Jan Filip, Varma R.S., Sharma V.K., Radek Zbořil Ferrate(VI)-Prompted Removal of Metals in Aqueous Media: Mechanistic Delineation of Enhanced Efficiency via Metal Entrenchent in Magnetic Oxides. Environ. Sci. Technol., 49 (4) (2015) 2319-2327.

[9] Yunho Lee, Lk-hwan Um, Jeyong Yoon Arsenic (III) Oxidation by Iron(VI) (Ferrate) and Subsequnt Removal of Aresenic(V) by Iron(III) Coagulation. Environ. Sci. Technol., 37 (24) (2003) 5750-5756.

[10] Ma Y.X., Zhang H.Z., Wang Y.H., Hu F.S., Li S.Q. Simultaneous Removal of Algae and Its Odorous Metabolite Dimethl Trisulfide in Water by Potassium Ferrate. Environmental Science, 5 (2013) 1767-1772.

[11] Jiang J.W., Chen L., Sudha Rani Batchu, Gardinali P.R., Libor Jasa, Blahoslav Marsalek, Radek Zboril, Dionysiou D.D., O'Shea K.E., Sharma V.K. Oxidation of Microcystin-LR by Ferrate(VI) :kinetics, Degradation Pathways, and Toxicity Assessments. Environ. Sci. Technol., 48 (20) (2014) 12164-12172

[12] Yang B., Ying G.G., Zhao L.J., Liu S.Y. Research Progess on the Oxidation of Emerging Organic contaminants by Ferrate(VI). Environmental Chemistry. 1 (2013) 54-64.

[13] Remsberg J.R., Rice C.P., Hyunook Kim, Osman Arikan, Chulhwan Moon Removal of Estrogenic Compounds in Dairy Waste Lagoons by Ferrate(VI). ACS Symposium Series, 985 (26) (2009) 420-433

[14] Myongjin Yu, Guisu Park, Hyunook Kim Oxidation of Nonyohenol Using Ferrate. ACS Symposium Series, 985 (24) (2009) 389-403. 
[15] Sharma V.K., George Anquandah, Hyunook Kim, Jiang Q.J., Radek Zboril Ferrate (VI) A Green Chemistry Oxidant for Removal of Antibiotics in Water. ACS Symposium Series, 1123 (3) (2013) 31-44.

[16] Anggita Karlesa, Glen Andrew D. De Vera, Dodd M.C., Jihye Park, Maria Pythias B. Espino, Yunho Lee Ferrate(VI) oxidation of $\beta$-lactam antibiotics: reaction kinetics, antibacterial activity changes, and transformation products. Environ.Sci.Technol., 48 (17) (2014) 10380-10389.

[17] Stuart Licht, Yu W.X. Recent Advance in Fe (VI) Charge Storage and Super-Iron Batteries. ACS Symposium Series, 985 (14) (2009) 197-256.

[18] Wood R.H. The Heat, Free Energy and Entropy of the Ferrate (VI) Ion. J. Am. Chem. Soc., 80 (9) (1958) 2038-2041.

[19] Benon H.J. Bielski, Thomas M.J. Studies of Hypervalent Iron in Aqueous Solutions. 1. Radiation-Induced Reduction of Iron (VI) to Iron (V) by CO2-. J. Am. Chem. Soc., 109 (25) (1987) 7761-7764.

[20] Thompson G.W., Ockerman L.T., Schreyer J.M. Preparation and Purification of Potassium Ferrate. VI. J. Am. Chem. Soc., 73(3) (1951) 1379-138.

[21] Johnson M.D., Read J.F. Kinetics of the Ferrate Oxidation of Thiosulfate and Other Sulfur-Containing. Species. Inorg. Chem, 35 (1996) 6795-6799.

[22] Carr J.D., Kelier P.B., et al Proceedings of Conference on Water Chlorination Chemistry Environment Impact Health Effects. Proc. Conf. 5 (1985) 1285-1298.

[23] Shan J.H., Liu Y.T. Kinetic and Mechanism of Substitution Reaction of Bis(N, N-Diethyldithiocarbamato) alkylxanthatocobalt (III) with Dipropylamine and Di-n-butylamine in Methanol. Acta Chim. Sinica, 52 (1994) 1140-1144. 